\title{
FAKTOR-FAKTOR YANG MEMPENGARUHI OPTIMALISASI PEMANFAATAN ASET TETAP
}

(Studi Pada Badan Pengelolaan Keuangan Dan Aset Daerah (BPKAD) Kabupaten Boven Digoel)

\author{
Pamfilia Ferdinanda Montayop ${ }^{8}$ \\ pamfilial84@gmail.com \\ Westim Ratang ${ }^{9}$ \\ westim_ratang@yahoo.co.id \\ Arius Kambu ${ }^{10}$ \\ ariusk16@gmail.com
}

\begin{abstract}
This article examines determinants which influence the optimisation of fixed assets utilisation in Local Treasury and Asset Management Agency of Boven Digoel Regency. The number of population in this study was 77 respondents from government officials and no... The final respondents were 69. A purposive sampling technique was used to select the respondents. A direct survey was employed to collect research data. This study used multiple regressions to empirically test the hypotheses.

The findings indicated that assets inventory positively influence fixed assets utilisation and management in Boven Digoel Regency. This infers that the improvements of assets inventory are likely to optimise fixed assets utilisation and management in Boven Digoel Regency. In addition, legal audit was positively associated with fixed assets utilisation and management. In other words, legal audit advancement is likely to optimise fixed assets utilisation and management in the Regency. Moreover, assets recognition was also positively associated with fixed assets utilisation and management in the Regency. This means that the better the assets recognition, the better the optimisation of fixed assets utilisation and management in Boven Digoel Regency.
\end{abstract}

Keywords: Asset Inventory, Legal Audit, Asset Recognition, Asset Optimisation.

\section{PENDAHULUAN}

Boven Digoel merupakan salah satu Kabupaten di Provinsi Papua dan sebelum di mekarkan Kabupaten Boven Digoel merupakan wilayah hukum Kabupaten Merauke. Hingga dikeluarkannya Undang-

\footnotetext{
$8 \quad$ Alumni Mahasiswa Magister Keuangan Daerah Universitas Cenderawasih

9, 10 Staf Dosen Jurusan Manajemen Fakultas Ekonomi dan Bisnis Universitas Cenderawasih
} 
Undang Republik Indonesia Nomor 26 Tahun 2002 maka pada tahun 2003 Boven Digoel resmi menjadi kabupaten yang berdiri sendiri. Sejak tahun 2003 hingga saat ini Kabupaten Boven Digoel dibentuk dengan 36 Instansi Pemerintah yang meliputi masing-masing 11 Dinas, 6 Badan, 2 Kantor dan 17 Distrik.

Tiga puluh enam Instansi yang merupakan unit Pemerintah Kabupaten Boven Digoel salah satunya termasuk Badan Pengelolaan Keuangan dan Aset Daerah (BPKAD). Kehadiran BPKAD sangat berperan aktif dalam menentukan pembangunan dan menginpentarisir serta mengelola semua aset daerah, baik itu aset tetap maupun aset lancar. Kebijakan Pemerintah Kabupaten Boven Digoel pada mulanya di prioritaskan pada pembebasan tanah adat untuk pembangunan kantorkantor pemerintah dan pembangunan rumah-rumah pegawai. Selain itu, dapat juga dilakukan pembangunan fisik (gedung kantor). Seiring berlajannya waktu, maka melalui pemilihan kepala daerah tahun 2005, Kabupaten Boven Digoel memiliki Bupati dan Wakil Bupati definitif. Namun kebijakan Pemerintah tidak mengikuti Kebijakan diambil sebelumnya. BPKAD selaku pengelola aset daerah seolah-olah tidak berperan aktif karena lebih mengarah pada kebijakan kepala daerah (Bulletin Suara Boven Digoel Tahun 2013, di download pada 8 Maret 2014 Jam 20:00).

Aset daerah merupakan bagian dari harta kekayaan daerah yang terdiri dari barang bergerak dan barang tidak bergerak yang dimiliki, dan dikuasai oleh Pemerintah Daerah, yang sebagian atau seluruhnya dibiayai dengan dana anggaran dan belanja daerah. Tanah dan bangunan merupakan aset daerah dalam bentuk barang tidak bergerak. Pengelolaan dan pemanfaatan aset daerah (khususnya tanah dan bangunan) yang optimal akan mendorong pertumbuhan ekonomi daerah yang pada akhimya akan berdampak pada peningkatan Pendapatan Asli Daerah (PAD) sebagai sumber pembiayaan daerah. Sebaliknya 
aset daerah yang tidak dikelola dan dimanfaatkan dengan optimal, akan memboroskan keuangan daerah melalui biaya pemeliharaan atas aset yang tidak sebanding dengan keuntungan (manfaat) yang dapat dihasilkan. Sebagai contohnya adalah banyak tanah dan bangunan milik Pemerintah Daerah yang terletak pada tempat-tempat strategis, dekat dengan pusat kegiatan ekonomi masyarakat, sehingga mempunyai nilai ekonomis yang tinggi namun tidak dikelola dan dimanfaatkan dengan baik karena tidak tersedianya dana.

Pengelolaan aset daerah merupakan salah satu dari kunci keberhasilan pengelolaan ekonomi daerah. Pentingnya pengelolaan aset secara tepat dan berdayaguna, dengan didasari prinsip pengelolaan yang efisien dan efektif diharapkan akan mampu memberi kekuatan kepada Pemerintah Daerah untuk membiayai pembangunan daerahnya. Pengelolaan aset negara yang profesional dan modern dengan mengedepankan good governance disatu sisi diharapkan akan mampu meningkatkan kepercayaan pengelolaan keuangan negara dari masyarakat.

Salah satu masalah utama dalam pengelolaan aset daerah (municipal aset management) adalah ketidaktertiban administrasi dalam pengendalian inventarisasi aset (Wardhana, 2005: 7). Karena inventarisasi aset ini merupakan hal yang sangat penting di dalam siklus pengelolaan aset. Aset tetap sebagai komponen utama dari aset daerah, oleh Pemerintah Daerah selanjutnya harus dapat dimanfaatkan sebagai aset yang produktif dan berguna, sehingga berdampak positif dalam pembangunan ekonomi daerah dan kesejahteraan masyarakat.

Dalam neraca keuangan daerah, aset dapat menjadi modal bila dapat menghasilkan pendapatan dimana hal ini dapat terjadi jika terdapat pengelolaan aset daerah yang optimal, sehingga dapat mendorong pertumbuhan ekonomi. Dalam mewujudkan tertib 
administrasi pengelolaan aset dan barang daerah dalam penyelenggaraan pemerintahan di daerah, terdapat tahapan dalam pengelolaan/manajemen aset daerah yaitu inventarisasi aset, legal audit, penilaian aset, optimalisasi pemanfaatan, serta pengawasan dan pengendalian aset.

Konsep Manajemen Aset Menurut Siregar (2004:518), di dunia internasional manajemen aset telah berkembang cukup pesat, namun di Indonesia hal ini khususnya dalam konteks pengelolaan aset pemerintah daerah sepenuhnya belum dipahami oleh para pengelola daerah. Manajemen aset pemerintah daerah dapat dibagi dalam lima tahap kerja yang meliputi; inventarisasi aset, legal audit, penilaian aset, optimalisasi pemanfaatan dan pengembangan SIMA (sistem informasi manajemen aset), di mana kelima tahapan tersebut adalah saling berhubungan dan terintegrasi satu dengan yang lainnya. Lebih jelas hal tersebut tersebut sebagai berikut (Siregar, 2004: 518-520).

1. Inventarisasi aset.

Inventarisasi Aset merupakan kegiatan yang terdiri dari dua aspek, yaitu inventarisasi fisik dan yuridis/legal. Aspek fisik terdiri atas bentuk, luas, lokasi, volume/jumlah, jenis, alamat dan lain-lain. Sedangkan aspek yuridis adalah status penguasaan, masalah legal yang dimiliki, batas akhir penguasaan. Proses kerja yang dilakukan adalah pendataan, kodifikasi/labelling, pengelompokkan dan pembukuan/administrasi sesuai dengan tujuan manajemen aset.

2. Inventarisasi aset.

Inventarisasi Aset merupakan kegiatan yang terdiri dari dua aspek, yaitu inventarisasi fisik dan yuridis/legal. Aspek fisik terdiri atas bentuk, luas, lokasi, volume/jumlah, jenis, alamat dan lain-lain. Sedangkan aspek yuridis adalah status penguasaan, masalah legal yang dimiliki, batas akhir penguasaan. Proses kerja yang dilakukan 
adalah pendataan, kodifikasi/labelling, pengelompokkan dan pembukuan/administrasi sesuai dengan tujuan manajemen aset.

3. Legal audit

Demikian menyangkut legal audit sebagai lingkup kerja manajemen aset yang berupa inventarisasi status penguasaan aset, sistem dan prosedur penguasaan atau pengalihan aset. Selanjutnya identifikasi dan mencari solusi atas permasalahan legal, dan strategi untuk memecahkan berbagai permasalahan legal yang terkait dengan penguasaan dan pengalihan aset. Masalah yang sering dihadapi dalam legal audit, menyangkut status penguasaan yang lemah, aset dikuasai pihak lain, pemindahan aset yang tidak termonitor dan lain lain.

4. Penilaian aset

Kesatuan kerja lanjutan dari manajemen aset, yaitu berupa kegiatan penilaian aset sebagai upaya penilaian atas aset yang dikuasai pemerintah daerah dan biasanya kegiatan ini dilakukan oleh konsultan penilaian independent. Hasil dari nilai tersebut akan dapat dimanfaatkan untuk mengetahui nilai kekayaan maupun informasi untuk penetapan harga bagi aset yang ingin dijual.

5. Optimalisasi aset

Selanjutnya optimalisasi aset merupakan kegiatan untuk mengoptimalkan potensi fisik, lokasi, nilai, jumlah/volume, legal dan ekonomi yang dimiliki aset tersebut. Dalam kegiatan ini aset-aset yang dikuasai Pemda diidentifikasi dan dikelompokkan atas aset yang memiliki potensi dan yang tidak memiliki potensi. Aset yang memiliki potensi dapat dikelompokkan berdasarkan sektor-sektor unggulan yang dapat menjadi tumpuan dalam strategi pengembangan ekonomi nasional, baik dalm jangka pendek, menengah, maupun jangka panjang. Untuk menentukan hal tersebut 
harus terukur dan trnsfaran, sedangkan aset yang tidak dapat dioptimalkan, harus dicari faktor penyebabnya, apakah faktor permasalahan legal, fisik, nilai ekonomi yang rendah ataupun faktor lainnya, sehinnga setiap aset nantinya memberikan nilai tersendiri. Hasil akhir dari tahapan ini adalah rekomendasi yang berupa sasaran, strategi dan program untuk mengoptimalkan aset yang dikuasai.Demikian menyangkut legal audit sebagai lingkup kerja manajemen aset yang berupa inventarisasi status penguasaan aset, sistem dan prosedur penguasaan atau pengalihan aset. Selanjutnya identifikasi dan mencari solusi atas permasalahan legal, dan strategi untuk memecahkan berbagai permasalahan legal yang terkait dengan penguasaan dan pengalihan aset. Masalah yang sering dihadapi dalam legal audit, menyangkut status penguasaan yang lemah, aset dikuasai pihak lain, pemindahan aset yang tidak termonitor dan lain lain.

6. Penilaian aset

Kesatuan kerja lanjutan dari manajemen aset, yaitu berupa kegiatan penilaian aset sebagai upaya penilaian atas aset yang dikuasai pemerintah daerah dan biasanya kegiatan ini dilakukan oleh konsultan penilaian independent. Hasil dari nilai tersebut akan dapat dimanfaatkan untuk mengetahui nilai kekayaan maupun informasi untuk penetapan harga bagi aset yang ingin dijual.

7. Optimalisasi aset

Selanjutnya optimalisasi aset merupakan kegiatan untuk mengoptimalkan potensi fisik, lokasi, nilai, jumlah/volume, legal dan ekonomi yang dimiliki aset tersebut. Dalam kegiatan ini aset-aset yang dikuasai Pemda diidentifikasi dan dikelompokkan atas aset yang memiliki potensi dan yang tidak memiliki potensi. Aset yang memiliki potensi dapat dikelompokkan berdasarkan sektor-sektor 
unggulan yang dapat menjadi tumpuan dalam strategi pengembangan ekonomi nasional, baik dalm jangka pendek, menengah, maupun jangka panjang. Untuk menentukan hal tersebut harus terukur dan trnsfaran, sedangkan aset yang tidak dapat dioptimalkan, harus dicari faktor penyebabnya, apakah faktor permasalahan legal, fisik, nilai ekonomi yang rendah ataupun faktor lainnya, sehinnga setiap aset nantinya memberikan nilai tersendiri. Hasil akhir dari tahapan ini adalah rekomendasi yang berupa sasaran, strategi dan program untuk mengoptimalkan aset yang dikuasai.

Harus dipahami betul oleh Pemerintah Daerah bahwa sasaran akhir atau tujuan utama pengelolaan aset adalah terjadinya optimalisasi dalam pemanfaatan aset daerah. Kenyataan sampai saat ini aset daerah masih dikelolah seadanya, sebatas inventarisasi belaka (pencatatan akuntansi). Aset daerah masih dikonsultasikan dengan arus kas negatif, dibanding sebagai aset yang produktif dan memberikan pendapatan. Kondisi pemanfaatan terhadap aset daerah tersebut membuktikan bahwa aset daerah sebagai sumber daya lokal daerah menunjukkan utilitasnya yang masih rendah, hal ini terjadi karena dihampir seluruh Pemerintah Daerah di Indonesia.

Pemilihan Kabupeten Boven Digoel didasari pada pertimbangan realita menyangkut aset tetap yang ada pada daerah tersebut. Berdasarkan studi pendahuluan melalui wawancara dan observasi pada Badan Pengelolaan Keuangan dan Aset Daerah (BPKAD) Kabupeten Boven Digoel, ditemukan bahwa sejak dimekarkannya Kabupaten Boven Digoel tahun 2004 sampai dengan saat ini pemerintah daerah melalui BPKAD belum dapat menginventarisir aset tetap daerah tersebut, terbukti masih banyak aset tetap (khususnya tanah dan bangunan) pemerintah kabupaten yang relatif tidak produktif atau tidak digunakan sebagaimana mestinya. 
Berdasarkan uraian diatas tujuan penelitian ini adalah untuk mengetahui dan menganalisis besarnya pengaruh inventarisasi asset, legal audit asset, serta penilaian Aset baik secara parsial maupun simultan terhadap optimalisasi pengelolaan dan pemanfaatan aset tetap pada Pemerintah Kabupaten Boven Digoel.

\section{METODE PENELITIAN}

\section{Hipotesa}

Hipotesis penelitian yang dikemukakan adalah diduga;

$\mathrm{H} 1$ : Inventarisasi aset berpengaruh positif dan signifikan terhadap optimalisasi pengelolaan dan pemanfaatan aset tetap pada Pemerintah Kabupaten Boven Digoel

$\mathrm{H} 2$ : Legal audit berpengaruh positif dan signifikan terhadap optimalisasi pengelolaan dan pemanfaatan aset tetap pada Pemerintah Kabupaten Boven Digoel

H3 : Penilaian aset berpengaruh positif dan signifikan terhadap optimalisasi pengelolaan dan pemanfaatan aset tetap pada Pemerintah Kabupaten Boven Digoel

H4 : inventarisasi aset, legal audit dan penilaian aset secara simultan berpengaruh terhadap optimalisasi pengelolaan dan pemanfaatan aset tetap pada Pemerintah Kabupaten Boven Digoel

\section{Desain Penelitian}

Penelitian ini digolongkan sebagai penelitian penjelasan (eksplanatory) karena berupaya untuk menjelaskan pengaruh variabel inventarisasi aset tetap, legal audit aset tetap dan penilaian aset tetap terhadap optimalisasi pemanfaatan aset tetap. Pendekatan dalam penelitian ini termasuk dalam penelitian kuantitatif, model penelitiannya adalah model survei dengan menggunakan instrument kuesioner dengan maksud untuk 
mendapatkan data opini individu responden (Jogiyanto, 2008) serta dilakukan pengujian hipotesis. Lokasi Penelitian berada pada Kantor Badan Pengelolaan Keuangan dan Aset Daerah (BPKAD) Kabupaten Boven Digoel.

\section{Populasi dan Sampel Penelitian}

Teknik penarikan sampel yang digunakan dalam penelitian ini menggunakan metode probability sampling. sementara teknik penarikan sampel yang digunakan adalah teknik purposive sampling, dengan kriteria penarikan sampel sebagai berikut;

a. Pegawai yang telah bekerja minimal 2 tahun.

b. Pegawai tersebut adalah Pegawai Negeri Sipil (PNS) dan honor yang pernah tugasnya berhubungan langsung dengan penyusunan APBD.

Berdasarkan kriteria tersebut maka sampel penelitian yang berhasil dimintai informasi untuk keperluan pengolahan data adalah sebanyak 69 responden. Jika melihat besarnya ukuran sampel minimal yakni 30 (Sekaran, 2006) maka jumlah sampel penelitian ini sudah cukup dan layak untuk dianalisis lebih lanjut.

\section{Definisi Operasional}

Sesuai dengan konsep yang telah dirumuskan dan telah dijelaskan terdahulu, maka variabel yang akan dianalisis dalam penelitain ini meliputi, variabel inventarisasi aset, legal audit, penilaian aset dan optimalisasi aset. Secara lengkap operasionalisasi variabel-variabel tersebut dapat dijelaskan sebagai berikut.

a. Inventarisasi Aset merupakan kegiatan yang terdiri dari dua aspek, yaitu inventarisasi fisik dan yuridis/legal. Aspek fisik terdiri atas bentuk, luas, lokasi, volume/jumlah, jenis, alamat dan lain- 
lain. Sedangkan aspek yuridis adalah status penguasaan, masalah legal yang dimiliki, batas akhir penguasaan. Variabel ini diukur melalui 2 (dua) indikator yaitu; inventarisasi fisik dan inventarisasi yuridis/legal yang terwakili melalui 4 (empat) pernyataan yang menggunakan skala likert yang dimulai dengan dari sangat tidak setuju dengan skor 1 hingga sangat setuju dengan skor 5 .

b. Legal Audit yang dimaksudkan dalam penelitian ini merupakan lingkup kerja manajemen aset yang berupa inventarisasi status penguasaan aset, sistem dan prosedur penguasaan atau pengalihan aset. Variabel ini diukur melalui 2 (dua) indikator yaitu; lingkup kerja manajemen aset dan masalah legal aset yang terwakili melalui 4 (empat) pernyataan yang menggunakan skala likert yang dimulai dengan dari sangat tidak setuju dengan skor 1 hingga sangat setuju dengan skor 5 .

c. Penilaian aset merupakan suatu kesatuan kerja lanjutan dari manajemen aset, yaitu berupa kegiatan penilaian aset sebagai upaya penilaian atas aset yang dikuasai pemerintah daerah dan biasanya kegiatan ini dilakukan oleh konsultan penilaian independent. Variabel ini diukur melalui 1 (satu) indikator yaitu; kegiatan penilaian aset yang terwakili melalui 3 (tiga) pernyataan yang menggunakan skala likert yang dimulai dengan dari sangat tidak setuju dengan skor 1 hingga sangat setuju dengan skor 5 .

d. Optimalisasi aset merupakan kegiatan untuk mengoptimalkan potensi fisik, lokasi, nilai, jumlah/volume, legal dan ekonomi yang dimiliki aset tersebut. Variabel ini diukur melalui 3 (tiga) indikator yaitu; inventarisasi aset, legal audit dan penilaian aset yang terwakili melalui 4 (empat) pernyataan yang menggunakan skala likert yang dimulai dengan dari sangat tidak setuju dengan skor 1 hingga sangat setuju dengan skor 5 . 


\section{Uji Instrumen Penelitian}

a. Uji Validitas

Uji validitas menunjukan sejauh mana tingkat efektivitas alat pengukur didalam melakukan pengukuran (Agusty, 2006:16). Uji validitas dalam penelitian ini menggunakan rumus korelasi Product Moment Person, dimana valid atau tidaknya instrumen dapat diketahui dengan membandingkan indeks korelasi Product Moment Person dengan signifikan 5\%.

Formula korelasi Product Moment Person adalah sebagai berikut;

$$
r=\frac{n \sum X Y-\sum X \sum Y}{\sqrt{n \sum X^{2}-\left(\sum \llbracket X\right)^{2} \rrbracket\left[n \sum Y^{2}-\left(\sum Y\right)^{2}\right]}}
$$

$$
\begin{aligned}
& \text { Keterangan; } \\
& \mathrm{n}=\text { banyaknya sampel } \\
& \mathrm{X}=\text { nilai atau skor } \mathrm{X} \\
& \mathrm{Y}=\text { nilai atau skor } \mathrm{Y}
\end{aligned}
$$

b. Uji Reliabilitas

Reliabilitas adalah indeks yang menunjukan sejauh mana suatu alat ukur dapat dipercaya atau diandalkan. Dalam penelitian ini, pengujian reliabilitas menggunakan Alpha cronbachs. Suatu instrumen dapat dikatakan reliabel jika memiliki nilai koefisien keandalan lebih besar atau sama dengan 0,6 artinya apabila $\alpha=$ 0,6 maka instrumen dapat dikatakan reliabel. Dengan rumus sebagai berikut;

$$
\begin{aligned}
& \mathrm{r} 11=\left(\frac{\boldsymbol{k}}{\boldsymbol{k}-1}\right)\left(1 \frac{\sum \delta b^{2}}{\delta 1^{2} t}\right) \\
& \text { Keterangan : } \\
& \mathrm{r} 11=\text { reliabilitas Instrumen } \\
& \mathrm{k}=\text { banyaknya butir pernyataan atau banyaknya } \\
& \sum \sigma^{2} b=\text { jumlah varaians butir } \\
& \sigma 1^{2}=\text { varians total }
\end{aligned}
$$




\section{Pengujian Asumsi Klasik}

a. Uji Normalitas

Tujuan asumsi normalitas data adalah untuk menguji apakah variabel independen dan variabel dependen, atau keduanya dalam suatu model regresi berdistribusi normal atau tidak. Model regresi yang baik jika data variabelnya berdistribusi mendekati normal atau normal sama sekali (Sunyoto, 2012 ; 119). Salah satu cara untuk mendeteksi normalitas data adalah dengan menggunakan normal probability plot yang pada prinsipnya suatu data ril dikatakan berdistribusi normal jika data ril mengikuti garis diagonal.

b. Uji Multikolinieritas

Multikolinieritas berarti adanya hubungan yang sempurna atau pasti diantara beberapa atau semua variabel yang menjelaskan garis regresi. Model regresi yang baik seharusnya tidak terjadi korelasi diantara variabel independen. Cara mendeteksi ada tidaknya gejala multikolinieritas adalah dengan melihat nilai Variance Inflation Factor (VIF) atau faktor pertambahan ragam. Apabila nilai VIF lebih besar dari 10 maka terjadi multikolinieritas, sebaliknya apabila VIF lebih kecil dari 10 maka tidak terjadi multikolinieritas.

c. Uji Heteroskedastisitas

Tujuan asumsi Heteroskedastisitas adalah untuk menguji apakah dalam sebuah model regresi terdapat ketidaksamaan varians dari satu pengamatan ke pengamatan yang lain. Jika varians residual dari suatu pengamatan yang lain tetap, maka disebut homoskedastisitas. Jika varians berbeda, disebut heteroskedastisitas. 
Priyatno, (2012: 87) menyatakan bahwa model regresi yang baik seharusnya tidak terjadi heteroskedastisitas. Pengujian heteroskedastisitas dalam kajian ini adalah dengan melihat penyebaran titik-titik pada grafik scatterplot yang kriterianya yaitu;

1) Jika ada pola tertentu seperti titik-titik yang ada membentuk suatu pola tertentu yang teratur (bergelombang, melebar kemudian menyempit), maka terjadi heterokedastisitas.

2) Jika tidak ada pola yang jelas, serta titik-titik menyebar diatas dan dibawah angka 0 pada sumbu $\mathrm{Y}$, maka tidak terjadi heterokedastistas.

\section{Analisa Regresi Berganda}

Metode ini digunakan untuk mengetahui variabel yang dominan memberi sumbangan terhadap variabel terikat dan untuk mengetahui pengaruh antara dua variabel atau lebih, yaitu variabel bebas dan variabel terikat. Rumusnya (unstandardized coefficients) adalah:

$$
Y=a+b 1 X 1+b 2 X 2+b 3 X 3+\varepsilon
$$

Keterangan;

$Y=$ Optimalisasi pemanfaatan aset tetap

$\alpha=$ Intercept

$\mathrm{b}=$ Koefisien regresi

$\mathrm{X} 1=\quad$ Inventarisasi aset tetap

$\mathrm{X} 2=\quad$ Legal audit aset tetap

$\mathrm{X} 3=$ Penilaian aset tetap

$\varepsilon=$ residual

\section{Pengujian Hipotesa}

Uji hipotesis dalam penelitian ini menggunakan uji $t$ dengan tingkat signifikannya $5 \%$. Kriteria pengujiannya adalah; jika thitung $>t$ tabel maka $\mathrm{HO}$ ditolak dan $\mathrm{Ha}$ diterima artinya terdapat pengaruh variabel independen (inventarisasi aset tetap, legal audit aset tetap dan penilaian aset tetap) terhadap variabel dependen (optimalisasi pemanfaatan aset tetap) pada Pemerintah Kabupaten Boven Digoel. 


\section{HASIL DAN PEMBAHASAN}

\section{Karakteristik Responden}

Pada bagian ini akan dijelaskan tentang gambaran karakteristik responden sebanyak 69 pegawai Badan Pengelola Keuangan dan Aset Daerah (BPKAD) Kabupaten Boven Digoel berdasarkan jenis kelamin, usia, pendidikan dan masa kerja. Seperti yang terlihat pada tabel-tabel dibawah ini:

a. Karakteristik Responden Berdasarkan Jenis Kelamin Tabel 1. Karakteristik Responden Berdasarkan Jenis Kelamin

\begin{tabular}{|c|c|c|}
\hline Jenis Kelamin & Jumlah & Persentase \\
\hline Pria & 48 & 69.6 \\
\hline Wanita & 21 & 30.4 \\
\hline Jumlah & $\mathbf{6 9}$ & $\mathbf{1 0 0}$ \\
\hline
\end{tabular}

Sumber: Data primer, diolah (2014)

Data pada tabel 1 diatas terlihat menjelaskan bahwa responden yang berjenis kelamin laki-laki berjumlah 48 atau $69.6 \%$ responden, sedangkan responden perempuan berjumlah 21 atau $20.7 \%$ responden. Hal ini menunjukkan bahwa pegawai BPKAD Kebupaten Boven Digoel yang telah bekerja diatas 1 tahun dan tugas pokoknya berhubungan langsung dengan APBD didominasi oleh pegawai lakilaki.

b. Karakteristik Responden Berdasarkan Tingkat Pendidikan

Tabel 2.

Karakteristik Responden Berdasarkan Tingkat Pendidikan

\begin{tabular}{|c|c|c|}
\hline Tingkat Pendidikan & Jumlah & Persentase \\
\hline SMA/sederajat & 37 & 53.6 \\
\hline Diploma & 12 & 17.4 \\
\hline S1 & 20 & 29 \\
\hline Jumlah & 69 & 100 \\
\hline
\end{tabular}

Sumber: Data primer, diolah (2014) 
Berdasarkan tabel 2 diatas terlihat bahwa mayoritas responden berpendidikan SMA atau yang sederajat yakni sebanyak 37 orang responden atau $53.6 .7 \%$ dari total responden. Fakta ini mengindikasikan bahwa mayoritas pegawai BPKAD Kabupaten Boven Digoel dapat dikatakan belum memiliki kompetensi keilmuan yang baik.

c. Karakteristik Responden Berdasarkan Masa Kerja

Tabel 3.

Karakteristik Responden Berdasarkan Tingkat Pendidikan

\begin{tabular}{|c|c|c|}
\hline Masa Kerja & Jumlah & Persentase \\
\hline $2-5$ tahun & 5 & 7.3 \\
\hline $6-9$ tahun & 6 & 8.6 \\
\hline $10-13$ tahun & 12 & 17.4 \\
\hline $14-17$ tahun & 20 & 29 \\
\hline $18-21$ tahun & 11 & 15.9 \\
\hline $22-25$ tahun & 7 & 10.1 \\
\hline $26-29$ tahun & 5 & 7.3 \\
\hline $30-33$ tahun & 3 & 4.4 \\
\hline Jumlah & $\mathbf{6 9}$ & $\mathbf{1 0 0}$ \\
\hline
\end{tabular}

Sumber: Data primer, diolah (2014)

Data Tabel 3 menunjukan bahwa pegawai dengan masa kerja terendah yakni 2 sampai dengan 5 tahun sebanyak 5 atau 7.3 responden dan yang tertinggi sebanyak 30 sampai dengan 33 tahun sebanyak 3 atau 4.4 responden. Data diatas juga menerangkan bahwa masa kerja mayoritas pegawai selama 14 sampai dengan 17 tahun yakni sebanyak 20 orang pegawai atau $29 \%$. Gambaran ini mengungkapkan bahwa pegawai BPKAD Kabupaten Boven Digoel relatif telah lama mengabdi dan tentunya memiliki pengalaman yang relatif baik dalam menunjang tugasnya. 


\section{Pengujian Instrument}

a. Uji Validitas

Uji validitas dalam penelitian ini menggunakan rumus korelasi Product Moment Person, dimana valid atau tidaknya instrumen dapat diketahui dengan membandingkan indeks korelasi Product Moment Person dengan signifikan 5\%. Hasil pengujiannya terlihat pada tabel berikut ini.

Tabel 4.

Hasil Uji Validitas

\begin{tabular}{|c|c|c|c|c|c|}
\hline \multirow[t]{2}{*}{ Variabel } & \multirow[t]{2}{*}{ Indikator } & \multirow[t]{2}{*}{ Item } & \multicolumn{3}{|c|}{$\begin{array}{c}\text { Korelasi Product Moment } \\
\text { (r) }\end{array}$} \\
\hline & & & $\mathbf{R}$ & sig & Keterangan \\
\hline \multirow{4}{*}{$\begin{array}{c}\text { Inventarisasi } \\
\text { Aset } \\
\text { (X1) }\end{array}$} & \multirow{2}{*}{ Inventarisasi fisik } & $\mathrm{X}_{1.1}$ & 0.771 & 0.000 & Valid \\
\hline & & $\mathrm{X}_{1.2}$ & 0.739 & 0.000 & Valid \\
\hline & \multirow{2}{*}{$\begin{array}{l}\text { Inventarisasi } \\
\text { yuridis/legal }\end{array}$} & $\mathrm{X}_{1.3}$ & 0.811 & 0.000 & Valid \\
\hline & & $\mathrm{X}_{1.4}$ & 0.802 & 0.000 & Valid \\
\hline \multirow{4}{*}{$\begin{array}{l}\text { Legal audit } \\
\qquad(X 2)\end{array}$} & \multirow{2}{*}{$\begin{array}{c}\text { Lingkup kerja } \\
\text { manajemen asset }\end{array}$} & $\mathrm{X}_{2.1}$ & 0.766 & 0.000 & Valid \\
\hline & & $\mathrm{X}_{2.2}$ & 0.762 & 0.000 & Valid \\
\hline & \multirow{2}{*}{$\begin{array}{l}\text { Masalah legal } \\
\text { asset }\end{array}$} & $\mathrm{X}_{2.3}$ & $\begin{array}{c}0 . \\
814\end{array}$ & 0.000 & Valid \\
\hline & & $X_{2.4}$ & $\begin{array}{c}0 . \\
828\end{array}$ & 0.000 & Valid \\
\hline \multirow{3}{*}{$\begin{array}{c}\text { Penilaian } \\
\text { aset } \\
(\mathrm{X} 3) \\
\end{array}$} & \multirow{3}{*}{$\begin{array}{c}\text { Kegiatan } \\
\text { penilaian asset }\end{array}$} & $X_{3.1}$ & 0.914 & 0.000 & Valid \\
\hline & & $X_{3.2}$ & 0.824 & 0.000 & Valid \\
\hline & & $\mathrm{X}_{3.3}$ & 0.923 & 0.000 & Valid \\
\hline \multirow{4}{*}{$\begin{array}{c}\text { Optimalisasi } \\
\text { aset } \\
\text { (Y) }\end{array}$} & $\begin{array}{c}\text { Persepsi } \\
\text { inventasasi asset }\end{array}$ & $\mathrm{Y}_{1.1}$ & 0.817 & 0.000 & Valid \\
\hline & $\begin{array}{l}\text { Persepsi legal } \\
\text { audit }\end{array}$ & $Y_{1.2}$ & 0.860 & 0.000 & Valid \\
\hline & \multirow{2}{*}{$\begin{array}{c}\text { Persepsi } \\
\text { penilaian asset }\end{array}$} & $Y_{1.3}$ & 0.883 & 0.000 & Valid \\
\hline & & $\mathrm{Y}_{1.4}$ & 0.912 & 0.000 & Valid \\
\hline
\end{tabular}

Sumber: Data primer, diolah (2014)

b. Uji Reliabilitas

Pengujian reliabilitas dalam kajian ini menggunakan formula alpha cronbach. Berikut ini hasil pengujian reliabilitas yang terlihat pada tabel dibawah ini. 
Tabel 5.

Hasil Uji Reliabilitas

\begin{tabular}{|c|c|c|}
\hline Variabel & $\begin{array}{c}\text { Koefisien } \\
\text { Alpha }\end{array}$ & Keterangan \\
\hline Inventarisasi asset & 0.780 & Reliabel \\
\hline Legal audit & 0.795 & Reliabel \\
\hline Penilaian asset & 0.865 & Reliabel \\
\hline Optimalisasi asset & 0.904 & Reliabel \\
\hline
\end{tabular}

Sumber: Data primer, diolah (2014)

\section{Analisa Regresi}

Berikut adalah hasil pengujian dengan menggunakan analisis regresi berganda dengan menggunakan bantuan software SPSS (Statistikal Package for Social Science) versi 21.0. seperti yang terlihat pada Tabel dibawah ini:

Tabel 6

Hasil Analisis Regresi

\begin{tabular}{|l|c|c|c|c|}
\hline \multicolumn{1}{|c|}{ Variabel } & $\begin{array}{c}\text { Standardized } \\
\text { Coefficients }\end{array}$ & $\begin{array}{c}\mathbf{t} \\
\text { hitung }\end{array}$ & Sig & Keterangan \\
\hline Constant & 1.280 & & \\
\hline Inventarisasi asset & 0.168 & 2.470 & 0.016 & Signifikan \\
\hline Legal audit & 0.536 & 5.429 & 0.000 & Signifikan \\
\hline Penilaian asset & 0.279 & 2.565 & 0.013 & Signifikan \\
\hline $\mathrm{R}$ & \multicolumn{5}{|c|}{0.946} \\
\hline R square & \multicolumn{5}{|c|}{0.896} \\
\hline Adusted R square & \multicolumn{5}{|c|}{186.121} & 0.000 & Signifikan \\
\hline $\mathrm{t}$ tabel & \multicolumn{5}{|c|}{2.746} \\
\hline F & \multicolumn{5}{|c|}{} \\
\hline F tabel & \multicolumn{5}{|c|}{} \\
\hline
\end{tabular}

Sumber: Data primer, diolah (2014)

Dari tabel diatas menunjukan bahwa persamaan regresi dalam penelitian ini adalah sebagai berikut;

$$
\begin{aligned}
& Y=\alpha+b_{1} X_{1}+b_{2} X_{2}+b_{3} X_{3}+\varepsilon \\
& Y=1.280+0.168 X_{1}+0.536 X_{2}+0.279 X_{3}+\varepsilon
\end{aligned}
$$




\section{a. Uji t}

Tabel diatas menunjukan nilai konstanta atau intercept sebesar 1.280 mengartikan bahwa jika tidak ada kenaikan nilai dari variabel inventarisasi aset, legal audit dan penilaian aset maka besarnya adalah nilai variabel optimalisasi aset adalah sebesar 1.280 .

$b_{1} X_{1}=0.168$ koefisien regresi menunjukkan bahwa setiap variabel inventarisasi aset meningkat atau semakin baik maka variabel optimalisasi aset akan meningkat sebesar nilai koefisien regresi $b_{1} X_{1}$ atau dengan kata lain setiap peningkatan variabel optimalisasi aset dibutuhkan nilai variabel inventarisasi aset sebesar 0.168 dengan asumsi besarnya nilai legal audit dan penilaian aset adalah tetap.

$b_{2} X_{2}=0.536$ koefisien regresi menunjukkan bahwa setiap variabel legal audit meningkat atau semakin baik maka variabel optimalisasi aset akan meningkat sebesar nilai koefisien regresi $\mathrm{b}_{2} \mathrm{X}_{2}$ atau dengan kata lain setiap peningkatan variabel optimalisasi aset dibutuhkan nilai variabel legal audit sebesar 0.536 dengan asumsi besarnya nilai inventarisasi aset dan penilaian aset adalah tetap.

$b_{3} X_{3}=0.279$ koefisien regresi menunjukkan bahwa setiap variabel penilaian aset meningkat atau semakin baik maka variabel optimalisasi aset akan meningkat sebesar nilai koefisien regresi $b_{3} X_{3}$ atau dengan kata lain setiap peningkatan variabel optimalisasi aset dibutuhkan nilai variabel penilaian aset sebesar 0.279 dengan asumsi besarnya nilai inventarisasi aset dan legal audit adalah tetap.

Data diatas juga menunjukan bahwa model konseptual penelitian yang dibangun adalah layak karena terbukti bahwa optimasasi aset dapat dijelaskan oleh inventarisasi aset, legal audit dan penilaian aset dengan nilai determinasi atau tingkat 
kelayakan yang relatif baik yakni sebesar 0.891 atau sebesar $89.1 \%$ sementara $10.9 \%$ lainnya dijelaskan oleh variabel lain yang tidak diuji dalam model konseptual penelitian ini.

b. Uji F

Untuk menguji pengaruh variabel independen secara simultan, digunakan uji $\mathrm{F}$. untuk pengambilan keputusan akan dilihat tingkat signifikansinya, jika $<0.05$, maka ada pengaruh secara simultan dari variabel independen (inventarisasi aset, legal audit dan penilaian aset) terhadap variabel dependen (optimalisasi aset) di Kabupaten Boven Digoel.

\section{Pengujian Hipotesis}

Berdasarkan hasil analisis ditemukan bahwa inventarisasi aset berpengaruh secara positif dan signifikan terhadap optimalisasi penggunaan dan pemanfaatan aset di Kabupaten Boven Digoel. Hal ini ditunjukan dengan nilai signifikansi sebesar 0.016 (probabilitas < $0.05)$. Nilai $t_{\text {hitung }}$ sebesar 2.470 sedangkan $t_{\text {tabel }} 1.667$ sehingga $t_{\text {hitung }}$ $>t_{\text {tabel }}(2.470>1.667)$ dengan nilai koefisien regresi adalah sebesar 0.168 . Hasil pengujian ini menunjukan bahwa hipotesis pertama diterima.

Hasil Kajian ini mendukung kajian yang dilakukan oleh Wijayanti (2010), Ilham (2013) dan Wahyuni 2012 yang telah membuktikan bahwa inventarisasi aset berpengaruh positif terhadap optimalisasi pemanfaatan dan penggunaan aset. Berdasarkan hasil analisis menunjukan bahwa legal audit berpengaruh secara positif dan signifikan terhadap optimalisasi penggunaan dan pemanfaatan aset di Kabupaten Boven Digoel. Hal ini ditunjukan dengan nilai signifikansi sebesar 0.000 (probabilitas $<0.05$ ). Nilai $t_{\text {hitung }}$ sebesar 5.429 sedangkan $t_{\text {tabel }} 1.667$ sehingga $t_{\text {hitung }}>t_{\text {tabel }}(5.429>1.667)$ 
dengan nilai koefisien regresi adalah sebesar 0.536 . Hasil pengujian ini menunjukan bahwa hipotesis kedua diterima.

Hasil kajian ini mendukung kajian yang dilakukan oleh Ilham (2013) Wahyuni, (2012) dan Setiawan (2013) yang telah membuktikan bahwa ilegal audit terbukti secara signifikan terhadap optimalisasi penggunaan dan pemanfaatan aset. Berdasarkan hasil analisis menunjukan bahwa penilaian aset berpengaruh secara positif dan signifikan terhadap optimalisasi penggunaan dan pemanfaatan aset di Kabupaten Boven Digoel. Hal ini ditunjukan dengan nilai signifikansi sebesar 0.013 (probabilitas $<0.05$ ). Nilai $t_{\text {hitung }}$ sebesar 2.565 sedangkan $t_{\text {tabel }} 1.667$ sehingga $t_{\text {hitung }}>t_{\text {tabel }}(2.565>1.667)$ dengan nilai koefisien regresi adalah sebesar 0.279 . Hasil pengujian ini menunjukan bahwa hipotesis ketiga diterima.

Hasil kajian ini mendukung Hasil analisis menunjukan bahwa penilaian aset, legal audit dan penilaian aset secara simultan berpengaruh positif dan signifikan terhadap optimalisasi penggunaan dan pemanfaatan aset di Kabupaten Boven Digoel. Hal ini ditunjukan dengan nilai signifikansi sebesar 0.000 (probabilitas $<0.05$ ). Nilai $F_{\text {hitung }}$ sebesar 186.121 sedangkan $F_{\text {tabel }} 2.746$ sehingga $F_{\text {hitung }}>F_{\text {tabel }}$ $(186.121>2.746)$. Hasil pengujian ini menunjukan bahwa hipotesis keempat diterima.

Pengujian secara statistik membuktikan bahwa inventarisasi aset, legal audit dan penilaian aset berpengaruh positif dan signifikan terhadap optimalisasi pengelolaan dan pemanfaatan aset tetap pada pemerintah Kabupaten Boven Digoel baik secara parsial maupun secara simultan. Hasil pengujian ini secara statistik membuktikan bahwa seluruh hipotesis penelitian yang diajukan dapat diterima. Hal ini dapat 
dilihat dari nilai parameter atau koefisien regresi yang membuktikan bahwa jika inventarisasi aset, legal audit dan penilaian aset meningkat atau semakin baik maka optimalisasi pengelolaan dan pemanfaatan aset tetap pada pemerintah Kabupaten Boven Digoel juga semakin meningkat. Dengan demikian maka dapat dijustifikasi bahwa dorongan peningkatan inventarisasi aset, legal audit dan penilaian aset akan meningkatkan optimalisasi pengelolaan dan pemanfaatan aset tetap pada pemerintah Kabupaten Boven Digoel. Untuk lebih jelas, pembahasan hasil kajian ini akan diulas per masing-masing variabel berikut ini.

\section{Pengaruh Hubungan Inventarisasi Aset Terhadap Optimalisasi Pemanfaatan Aset Tetap}

Variabel inventarisasi aset dalam kajian ini diukur melalui 2 indikator yakni inventarisasi fisik dan inventarisasi yuridis/legal. Hasil analisis menunjukan bahwa aspek inventarisasi fisik akan semakin baik jika mencakup beberapa item antara lain; bentuk, luas, lokasi, volume/jumlah dan jenis. Disamping itu, hasil analisis juga menunjukan bahwa inventarisasi legal/yuridis juga akan semakin baik jika mencakup aspek; penguasaan, batas akhir masa penguasaan dan yang tidak kalah penting juga adalah masalah legal/yuridis yang melekat pada aset tetap tersebut.

Hasil ini secara tidak langsung membuktikan bahwa inventarisasi aset adalah haruslah dilakukan secara periodik karena aset merupakan sumberdaya yang penting bagi pemerintah daerah. Inventarisasi perlu dilaksanakan agar pemerintah daerah khususnya di Kabupaten Boven Digoel dapat mengetahui secara pasti mengenai jumlah dan nilai kekayaan daerah yang dimilikinya, baik yang saat ini dikuasai maupun yang masih berupa potensi yang belum dikuasai atau dimanfaatkan seperti yang diungkapkan Mardiasmo, (2004). 
Hasil kajian ini juga selaras dengan kajian empiris oleh; Endang Widayanti, (2010), Ary Wahyuni, (2012), Fadli Ilham, (2013) dan Rinanda Aziza Septiana, (2013).

\section{Pengaruh Hubungan Legal Audit Terhadap Optimalisasi Pemanfaatan Aset Tetap}

Variabel lainnya adalah legal audit yang diukur melalui 2 indikator yakni; lingkup manajemen aset dan masalah yang terkait dengan legal aset pemerintah Kabupaten Boven Digoel. Hasil analisis variabel ini menunjukan beberapa beberapa temuan baru yakni; ternyata ada status kepemilikan aset khususnya tanah dan bangunan yang relative masih lemah (ada masalah legal terkait dengan penguasaan tanah dan bangunan tersebut) dan berikutnya adalah pengawasan terhadap proses pemindahan kepemilikan tanah yang juga masih relative lemah. Temuan mengindikasikan bahwa pelaksanaan legal audit yang mencakup inventarisasi status penguasaan aset, sistem dan prosedur penguasaann atau pengalihan aset serta masalah yang melekat pada aset tersebut menjadi hal penting yang tidak boleh diabaikan oleh pemerintah Kabupaten Boven Digoel. Temuan ini sejalan dengan hasil kajian empiris oleh; Endang Widayanti, (2010), Ary Wahyuni, (2012), Fadli Ilham, (2013), Jamaludin, (2013) dan Rinanda Aziza Septiana, (2013).

3. Pengaruh Hubungan Penilaian Aset Terhadap Optimalisasi Pemanfaatan Aset Tetap

Variabel terakhir dalam penelitian ini adalah penilaian aset (tanah dan bangunan) yang diukur melalui indicator kegiatan penilalain aset. Temuan melalui variabel ini antara lain; (1) penilaian tanah dan bangunan relatif tidak mencerminkan nilai yang sebenarnya karena kegiatan inventarisasi dan legal audit yang belum 
optimal dilaksanakan. (2) keakuratan penilaian aset akan berpengaruh terhadap nilai aset khususnya menyangkut nilai jual.

Penjelasan logis menyangkut penilaian aset ini akan mudah dipamahi jika kita melihat proses penyusunan neraca pemerintah. Dalam rangka menyusun neraca pemerintah perlu diketahui berapa jumlah aset negara sekaligus nilai dari aset tersebut. Untuk diketahui nilainya maka barang milik negara secara periodik harus dilakukan penilaian baik oleh pengelola barang dengan melibatkan penilai independent sehingga dapat diketahui nilai barang milik negara secara tepat. Untuk penilaian berupa tanah dan bangunan menggunakan patokan Nilai Jual Obyek Pajak (NJOP). Menurut Siregar (2004) penilaian aset merupakan suatu proses kerja untuk melakukan penilaian atas aset yang dikuasai. Untuk itu pemerintah daerah dapat melakukan outsourcing kepada konsultan penilai yang profesional dan independent. Hasil dari nilai tersebut akan dimanfaatkan untuk mengetahui nilai kekayaan maupun informasi untuk penetapan bagi aset yang akan dijual. Hasil ini selaras dengan hasil kajian empiris oleh; Agustina Ester Antoh, (2012), Ary Wahyuni, (2012), dan Jamaludin, (2013).

Berdasarkan Peraturan Pemerintah Republik Indonesia Nomor 6 Tahun 2006 tentang Pengelolaan Barang Milik Negara/Daerah dan Peraturan Menteri Dalam Negeri Nomor 17 Tahun 2007 tentang Pedoman Teknis Pengelolaan Barang Milik Daerah, pemanfaatan adalah pendayagunaan barang milik daerah yang tidak dipergunakan sesuai dengan tugas pokok dan fungsi Satuan Kerja Perangkat Daerah (SKPD) dalam bentuk sewa, pinjam pakai, kerjasama pemanfaatan, bangun guna serah dan bangun serah guna dengan tidak mengubah status kepemilikan. 
Sehubungan dengan pemanfaatan aset daerah khususnya berupa benda tidak bergerak yang berbentuk tanah atau bangunan/gedung, terutama yang belum didayagunakan secara optimal sehingga dapat memberikan value added, value in use dan mampu menaikkan nilai ekonomi aset bersangkutan, maka dapat dilaksanakan melalui penggunausahaan yaitu pendayagunaan aset daerah (tanah dan atau bangunan) oleh pihak ketiga (perusahaan swasta) dalam bentuk BOT (Build-Operate-Transfer), BTO (BuildTransfer-Operate), BT (Build-Transfer), KSO (Kerja Sama Operasi) dan bentuk lainnya (Siregar, 2004).

\section{KESIMPULAN DAN SARAN}

\section{Kesimpulan}

Berdasarkan pembahasan hasil peelitian maka kesimpulan penelitian yang dapat disampaikan antara lain;

a. Inventarisasi aset terbukti berpengaruh secara positif terhadap optimalisasi pengelolaan dan pemanfaatan aset tetap pada Kebupaten Boven Digoel. Hal ini berarti bahwa jika inventarisasi aset meningkat atau semakin baik maka tingkat optimalisasi pengelolaan dan pemanfaatan aset tetap pada Kebupaten Boven Digoel juga akan semakin baik atau bahwa dorongan peningkatan nilai inventarisasi aset akan meningkatkan pula tingkat optimalisasi pengelolaan dan pemanfaatan aset tetap pada Kebupaten Boven Digoel

b. Legal audit terbukti berpengaruh secara positif terhadap optimalisasi pengelolaan dan pemanfaatan aset tetap pada Kebupaten Boven Digoel. Hal ini berarti bahwa jika legal audit meningkat atau semakin baik maka tingkat optimalisasi pengelolaan dan pemanfaatan aset tetap pada Kebupaten Boven Digoel juga akan semakin baik atau bahwa dorongan peningkatan nilai legal audit akan meningkatkan pula tingkat 
optimalisasi pengelolaan dan pemanfaatan aset tetap pada Kebupaten Boven Digoel

c. Penilaian aset terbukti berpengaruh secara positif terhadap optimalisasi pengelolaan dan pemanfaatan aset tetap pada Kebupaten Boven Digoel. Hal ini berarti bahwa jika penilaian aset meningkat atau semakin baik maka tingkat optimalisasi pengelolaan dan pemanfaatan aset tetap pada Kebupaten Boven Digoel juga akan semakin baik atau bahwa dorongan peningkatan nilai penilaian aset akan meningkatkan pula tingkat optimalisasi pengelolaan dan pemanfaatan aset tetap pada Kebupaten Boven Digoel

\section{Saran}

Saran yang dapat disampaikan berdasarkan hasil penelitian ini adalah;

a. Perlu adanya perhatian yang lebih baik dari Pemerintah Kabupaten Boven Digoel menyangkut inventarisasi aset yang mencakup; inventarisasi fisik maupun inventarisasi legal/yuridis kerena dengan pelaksanaannya maka agar pemerintah daerah khususnya di Kabupaten Boven Digoel dapat mengetahui secara pasti mengenai jumlah dan nilai kekayaan daerah yang dimilikinya, baik yang saat ini dikuasai maupun yang masih berupa potensi yang belum dikuasai atau dimanfaatkan.

b. Perlunya adanya perhatian yang lebih baik dari Pemerintah Kabupaten Boven Digoel menyangkut pelaksanaan legal audit yang mencakup inventarisasi status penguasaan aset, sistem dan prosedur penguasaann atau pengalihan aset serta masalah yang melekat pada aset tersebut.

c. Perlunya adanya perhatian yang lebih baik dari Pemerintah Kabupaten Boven Digoel menyangkut pelaksanaan penilaian aset karena untuk diketahui nilai aset tanah dan bangunan maka 
barang milik Pemerintah Kabupaten Boven Digoel secara periodik harus dilakukan penilaian baik oleh pengelola barang dengan melibatkan penilai independent sehingga dapat diketahui nilai barang milik negara secara tepat. Untuk penilaian berupa tanah dan bangunan menggunakan patokan Nilai Jual Obyek Pajak (NJOP).

d. Pemerintah perlu melaksanakan pelatihan-pelatihan setiap tahun atau per semester terkait dengan pengelolaan dan pemanfaatan aset tetap di Kabupaten Boven Digoel.

\section{DAFTAR PUSTAKA}

Agusty Ferdinand, 2006. Metode Penelitian Manajemen: Pedoman Penelitian Untuk Penulisan Skripsi, Tesis, Dan Disertasi IImu Manajemen, Edisi Kedua, Badan Penerbit Universitas Diponegoro Semarang, Semarang.

Antoh E. Agustina, 2012. Manajemen Aset Dalam Rangka Optimalisasi Aset Tetap (Tanah dan Bangunan) Pemerintah Daerah (Studi di Kabupaten Paniai), Tesis UGM.

Fadli Ilham, 2013. Inventarisasi Aset, Legal Audit Aset, Penilaian Aset, Pengawasan dan Pengendalian Aset, Optimalisasi Aset Tetap (Tanah dan Bangunan), Tesis UGM.

Jamaludin, 2013. Optimalisasi Pengelolaan dan Pemanfaatan Aset Tetap (Tanah dan Bangunan) Studi Pada Pemda Provinssi NTB, Tesis, UGM.

Jogiyanto, 2008. Metodologi Penelitian Bisnis : Salah Kaprah dan Pengalaman - Pengalaman, Edisi Pertama, BPFE-Yogyakarta, Yogyakarta.

Mardiasmo, 2004. Otonomi dan Manajemen Keuangan Daerah, Good Governence Democratization, Local Government Financial Management, Public Polic, Reinventing Government, Accountability Probity, Vaalue for Money, Participatory Development, Serial Otonomi Daerah, Andi, Yogyakarta.

Priyatno D, 2012. Belajar Cepat Olah Data Statistik Dengan SPSS, Andi, Yogyakarta. 
Rinanda A, Septiana, 2013, Determinan Optimalisasi Aset Tetap (Tanah dan Bangunan) Pada Pemerintah Provinsi Kalimantan Selatan, Tesis, UGM.

Sekaran U, 2006. Research Methods For Bussiness - Metodologi Penelitian Untuk Bisnis (Penerjemah Kwan Men Yon), Buku I, Edisi 4, Salemba Empat, Jakarta.

Siregar Doli, D. 2004. Management Asset Strategi Penataan Konsep Pembangunan Berkelanjutan Secara Nasional dalam Konteks Kepala Daerah Sebagai CEO's Pada Era Globalisasi dan Otonomi Daerah, PT Gramedia Pustaka Utama, Jakarta.

Sunyoto D, 2012. Analisis Validitas dan Asumsi Klasik, Gava Media, Yogyakarta.

Wahyuni Ary. 2012. Pengaruh Manajemen Aset Terhadap Optimalisasi Pemanfaatan Aset Tetap pemerintah Kabupaten Sumbawa Barat, Tesis UGM.

Wardhana I, Henry, 2005. Mengelola Aset Kota Jakarta, Jurnal Kajian Pengembangan Perkotaan, Vol. 1, No, 1, 7-10.

Widayanti Endang, 2010. Pengaruh Manajemen Aset Terhadap Optimalisasi Pemanfaatan Aset Tetap Pemerintah Daerah Kabupaten Sragen, Tesis, Fakultas Ekonomi Program Studi Magister Akuntansi UGM.

http://asetdaerah,wordpress.com diakses hari kamis, 9 januari 2014, Pengelolaan aset daerah Sekretariat daerah Prov.Kaltim. 